\title{
Clostridium proteoclasticum sp. nov., a Novel Proteolytic Bacterium from the Bovine Rumen
}

\author{
G. T. ATTWOOD, ${ }^{1 *}$ K. REILLY, ${ }^{1}$ AND B. K. C. PATEL ${ }^{2}$ \\ AgResearch, Grasslands Research Centre, Palmerston North, New Zealand, ${ }^{1}$ and Faculty of Science and Technology, \\ Griffith University, Nathan, Brisbane, Queensland, Australia, $4111^{2}$
}

\begin{abstract}
A novel proteolytic bacterium was isolated from rumen contents of New Zealand cattle grazing fresh forage and was designated strain $B 316^{\mathrm{T}}$ ( $\mathrm{T}=$ type strain). Strain $\mathrm{B316}^{\mathrm{T}}$ cells were straight to slightly curved rods (width, 0.4 to $0.6 \mu \mathrm{m}$; length, 1.3 to $3.0 \mu \mathrm{m}$ ) that were gram-positive and possessed a single subterminal flagellum. This isolate did not produce catalase, indole, ammonia, lipase, or lecithinase or reduce nitrate, but it did produce a curd reaction with milk. Strain $\mathrm{B316}^{\mathrm{T}}$ was proteolytic, hydrolyzing casein and fraction I leaf protein. The crude proteinase was predominantly the serine type, but some cysteine proteinase and metalloproteinase activities were also detected. The DNA base composition of strain $\mathrm{B316}^{\mathrm{T}}$ was $28 \mathrm{~mol} \% \mathrm{G}+\mathrm{C}$. A $16 \mathrm{~S}$ ribosomal DNA sequence analysis of strain $\mathrm{B3}^{\mathrm{T}}{ }^{\mathrm{T}}$ indicated that it was most closely related to a member of clostridial cluster XIVa, viz., Clostridium aminophilum, an amino acid-fermenting organism isolated from the rumen; the similarity value was $\mathbf{9 2 . 2 \%}$. The results of the phenotypic characterization analysis, $\mathrm{G}+\mathrm{C}$ content analysis, and phylogenetic analysis of the $16 \mathrm{~S}$ ribosomal DNA sequence set strain $\mathrm{B316}^{\mathrm{T}}$ apart from all of the members of cluster XIVa. We propose that strain $\mathbf{B 3 1 6}^{\mathrm{T}}$ should be designated a new species of the genus Clostridium, Clostridium proteoclasticum. Strain B316 is the type strain and has been deposited in the American Type Culture Collection as strain ATCC 51982.
\end{abstract}

In New Zealand ruminants, the breakdown of plant protein in the rumen can lead to the loss of up to $50 \%$ of the available protein (14) and therefore to the inefficient use of pasture nitrogen. Bacteria are the most active proteolytic organisms in the rumen $(2,18)$, and their populations are influenced by the diet of the animal and the physical form of the feed. Many rumen bacteria are able to degrade protein, and members of the genera Prevotella, Ruminobacter, Selenomonas, Butyrivibrio, and Streptococcus are commonly identified as being proteolytic. More recently, members of the genera Peptostreptococcus and Clostridium have been identified as being important in peptide and amino acid fermentation in the rumen $(6,7,20)$. In a recent study of the proteolytic bacteria present in New Zealand cattle, species belonging to the genera Streptococcus, Eubacterium, and Butyrivibrio were identified as important members of the proteolytic flora (1). One highly proteolytic strain, strain $B 316^{\mathrm{T}}$ ( $\mathrm{T}=$ type strain), was initially identified as a Butyrivibrio-like organism. However, further phenotypic characterization and a phylogenetic analysis of the $16 \mathrm{~S}$ ribosomal DNA (rDNA) sequence of this strain identified it as a member of a new species of the genus Clostridium. We propose that this organism should be named Clostridium proteoclasticum sp. nov.

\section{MATERIALS AND METHODS}

Isolation and characterization of strain $\mathrm{B316}^{\mathrm{T}}$. Strain $\mathrm{B} 316^{\mathrm{T}}$ was isolated from a rumen sample from a cow grazing in a fresh pasture as described previously (1) Unless otherwise indicated, all procedures were carried out anaerobically in Hungate tubes under a $\mathrm{CO}_{2}$ atmosphere or in an anaerobic chamber containing a $92 \% \mathrm{CO}_{2}-8 \% \mathrm{H}_{2}$ atmosphere. Substrate utilization tests were performed with CC medium (13), and the substrates tested were added at the following final concentrations: adonitol, $0.5 \%$ (wt/vol); amygdalin, $0.5 \%$ (wt/vol); arabinose, $0.5 \%$ (wt/vol); cellobiose, $1.0 \%$ (wt/vol); cellulose, $1.0 \%$ (wt/vol); dextrin, $1.0 \%$ (wt/vol); dulcitol, $1.0 \%(\mathrm{wt} / \mathrm{vol})$; erythritol, $0.5 \%(\mathrm{wt} / \mathrm{vol})$; fructose, $1.0 \%(\mathrm{wt} / \mathrm{vol})$; galacturonic acid, $1.0 \%(\mathrm{wt} / \mathrm{vol})$; galactose, $1.0 \%(\mathrm{wt} / \mathrm{vol})$; glucose, $1.0 \%(\mathrm{wt} / \mathrm{vol})$;

* Corresponding author. Mailing address: AgResearch, Grasslands Research Centre, Tennent Drive, Private Bag 11008, Palmerston North, New Zealand. Phone: 646356 8019. Fax: 6463518003. Electronic mail address: attwoodg@agresearch.cri.nz. glycerol, $1.0 \%$ (wt/vol); glycogen, $0.5 \%$ (wt/vol); inositol, $1.0 \%(\mathrm{wt} / \mathrm{vol})$; inulin $1.0 \%(\mathrm{wt} / \mathrm{vol})$; lactate, $0.77 \%(\mathrm{wt} / \mathrm{vol})$; lactose, $1.0 \%(\mathrm{wt} / \mathrm{vol}) ;$ maltose, $1.0 \%$ (wt/vol); mannitol, $1.0 \%$ (wt/vol); mannose, $1.0 \%$ (wt/vol); melezitose, $0.5 \%$ (wt/vol); melibiose, $0.5 \%$ (wt/vol); rhamnose, $1.0 \%$ (wt/vol); salicin, $1.0 \%$ (wt $\mathrm{vol}$ ); sorbitol, $1.0 \%$ (wt/vol); sorbose, $1.0 \%$ (wt/vol); starch, $1.0 \%$ (wt/vol); sucrose, $1.0 \%(\mathrm{wt} / \mathrm{vol})$; trehalose, $0.5 \%(\mathrm{wt} / \mathrm{vol}) ;$ xylan, $1.0 \%(\mathrm{wt} / \mathrm{vol})$; and xylose, $1.0 \%(\mathrm{wt} / \mathrm{vol}) ;$. Routine growth of strain $\mathrm{B} 316^{\top}$ was carried out on CC-glucose medium, which is $\mathrm{CC}$ medium supplemented with $1.0 \%$ glucose. Blood agar plates for hemolysis tests were prepared from blood agar base supplemented with 5\% horse blood (Life Technologies, Auckland, New Zealand). End products of fermentation were analyzed by high-performance liquid chromatography (HPLC). Samples $(1 \mathrm{ml})$ of culture were centrifuged at $12,000 \times \mathrm{g}$ for $10 \mathrm{~min}$ at $4^{\circ} \mathrm{C}$, and $50 \mu \mathrm{l}$ of the supernatant was analyzed by using an Aminex type HPX $87 \mathrm{H}$ ion exclusion column attached to a Bio-Rad isocratic HPLC system; $5 \mathrm{mM}$ $\mathrm{H}_{2} \mathrm{SO}_{4}$ was used as the eluant. Peaks were detected with a differential refractometer, identified by comparison with standards, and integrated by using a Bio-Rad model 700 chromatography workstation (version 3.71). Gas chromatography (26) and growth stimulation and biochemical tests (11) were carricd out as previously described. Formation of endospores was investigated by growing cells on chopped meat agar slants (Oxoid, Basingstoke, United Kingdom) and staining for spores by the Schaeffer-Fulton method (9) and by the heat test (11). The $\mathrm{G}+\mathrm{C}$ content was estimated as previously described (19).

Proteinase assays and inhibitors. Proteinase assays were carried out as previously described (1) by using casein and fraction I leaf protein (FILP) labelled with fiuorescein (25). Inhibition assays were carried out by using the azocasein assay (5) and including inhibitors (Sigma Chemical Co., St. Louis, Mo.) at the following final concentrations: phenylmethylsulfonyl fluoride, $3 \mathrm{mM} ; N$-tosyl-1lysine chloromethyl ketone, $1 \mathrm{mM} ; N$-tosyl-1-phenylalanine chloromethyl ketone, $1 \mathrm{mM}$; EDTA, $10 \mathrm{mM}$; merthiolate, $5 \mathrm{mM}$; $p$-chloromercuribenzoate, 2.5 $\mathrm{mM}$; o-phenanthroline, $2.5 \mathrm{mM}$; and pepstatin A, $200 \mu \mathrm{g} \mathrm{ml}^{-1}$

Electron microscopy. Electron microscopy of negatively stained cells and of thin sections was carried out with a Philips model 201C electron microscope. Whole-cell preparations were negatively stained with $1 \%$ phosphotungstic acid and mounted on Formvar-coated copper grids. Thin sections were prepared from bacterial cell pellets as previously described (24)

rDNA analysis. DNA was extracted (21), and the ribosomal 16S gene was amplified by using the following universal primers in a PCR: primers fd1 (CCG AAT TCG TCG ACA ACA GAG TTT GAT CCT GGC TCA G) and rd1 (CCC GGG ATC CAA GCT TAA GGA GGT GAT CCA GCC). The PCR product was purified by using GlassMAX DNA isolation spin cartridges and digested with EcoRI and BamHI as recommended by the manufacturer (Gibco BRL, Life Technologies, Auckland, New Zealand). Because of an internal EcoRI site within the $\mathrm{B} 316^{\mathrm{T}} 16 \mathrm{~S}$ rRNA gene, two fragments resulted, and each fragment was ligated separately into appropriately digested pUC19. The ligated DNAs were used to transform competent Escherichia coli DH5a, and transformants containing 16S rRNA gene fragments were detected by bluc-white color selection and verified by plasmid minipreparations (15). The $16 \mathrm{~S}$ clones were sequenced (23) with a model 373A automated sequencer (Applied Biosystems, 


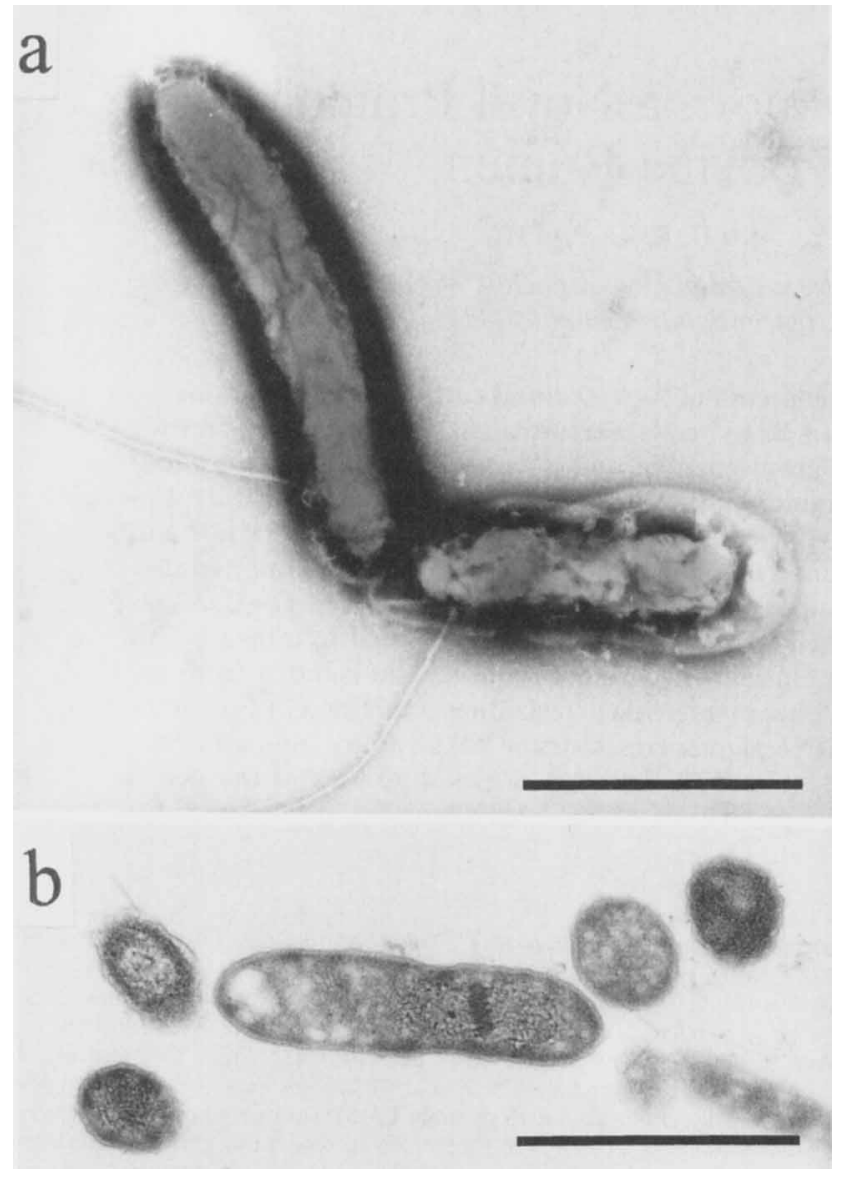

FIG. 1. Electron micrographs of negatively stained strain $B 316^{\mathrm{T}}$ cells, showing the flagellar arrangement (a), and thin-sectioned strain $\mathrm{B} 316^{\mathrm{T}}$ cells, showing the gram-positive cell wall structure (b). Bars $=1.0 \mu \mathrm{m}$.

Foster City, Calif.). M13 universal and reverse sequencing primers and the following internal primers for conserved regions of the $16 \mathrm{~S}$ rRNA gene (5' to $3^{\prime}$; E. coli numbering) were used to sequence both strands: primers $\mathrm{F} 1$ (positions 513 to 532; CGTGCCAGCAGCCGCGGTAA), F3 (positions 1094 to 1113; TCCCG CAACGAGCGCAACCC), R1 (positions 357 to 342 ; CTGCTGCCTCCCGT $\mathrm{AG}$ ), and R6 (positions 1113 to 1094; GGGTTGCGCTCGTTGCGGGA) Closely related sequences obtained from the Ribosomal Database Project were used to construct a similarity matrix (12), and a phylogenetic tree was constructed (22) by using 1,100 unambiguous bases.

Nucleotide sequence accession number. The 16S rDNA sequence of strain B $316^{\mathrm{T}}$ has been deposited in the GenBank data library under accession number U37378.

\section{RESULTS AND DISCUSSION}

A bacterial strain was isolated from high dilutions $\left(10^{-8}\right)$ of the rumen contents of a cow grazing in a mixed pasture which contained mainly ryegrass and clover. This strain, designated $\mathrm{B} 316^{\mathrm{T}}$, was a straight to slightly curved rod-shaped organism whose cells were 0.4 to $0.6 \mu \mathrm{m}$ in diameter and 1.3 to $3.0 \mu \mathrm{m}$ long and occurred in short chains. When grown overnight on $\mathrm{CC}$-glucose plates, strain $\mathrm{B} 316^{\mathrm{T}}$ produced tan transparent colonies that were $0.5 \mathrm{~mm}$ in diameter, irregular, and convex with undulate margins. The colonies were smooth and had a viscous consistency. After 2 to 3 days of incubation, the colonies were up to $1 \mathrm{~mm}$ in diameter and had a granular appearance. The cells were Gram reaction positive in young cultures and Gram reaction negative in older cultures; each cell had a single subterminal flagellum (Fig. 1a), and endospores were not ob- served. Electron microscopy of thin sections of strain B316 revealed a typical gram-positive cell wall architecture (Fig. 1b). Cultures of strain B316 ${ }^{\mathrm{T}}$ formed a ropy sediment after overnight incubation, which was easily dispersed upon shaking. Older cultures ( 2 to 3 days) produced phase-bright spherical cells which burst after dilution in distilled water, indicating that spheroplasts were formed. Growth occurred anaerobically at $39^{\circ} \mathrm{C}$ but not at 25 or $45^{\circ} \mathrm{C}$, and no growth occurred aerobically. Growth was inhibited on CC-glucose agar plates containing the antibiotics ampicillin $\left(10 \mu \mathrm{g} \mathrm{ml}^{-1}\right)$, tetracycline $\left(10 \mu \mathrm{g} \mathrm{ml}^{-1}\right)$, chloramphenicol $\left(10 \mu \mathrm{g} \mathrm{ml}^{-1}\right)$, gentamicin $\left(10 \mu \mathrm{g} \mathrm{ml}^{-1}\right)$, and monensin $\left(2.5 \mu \mathrm{g} \mathrm{ml}^{-1}\right)$; however, strain B316 ${ }^{\mathrm{T}}$ could grow in the presence of streptomycin concentrations up to $100 \mu \mathrm{g} \mathrm{ml} \mathrm{l}^{-1}$ but not in the presence of $150 \mu \mathrm{g}$ of streptomycin per $\mathrm{ml}$. Colonies grown on blood agar plates were nonhemolytic.

Substrate utilization and stimulation of growth. The substrates which supported growth were amygdalin, arabinose, cellobiose, fructose, galactose, glucose, glycogen (weak growth), inulin, lactose, maltose, mannose (weak growth), melibiose, rhamnose, salicin, starch, sucrose, xylan, and xylose. Adonitol, cellulose, dextrin, dulcitol, erythritol, galacturonic acid, glycerol, inositol, lactate, mannitol, melizitose, sorbitol, sorbose, and trehalose did not support growth. The final $\mathrm{pH}$ after growth on CC-glucose medium was 5.8. No growth occurred in the absence of fermentable carbohydrates. The fermentation end products from growth on $\mathrm{CC}$ medium included formate $(15.1 \mathrm{mM})$, butyrate $(4.8 \mathrm{mM})$, acetate $(1.4 \mathrm{mM})$, propionate $(1.2 \mathrm{mM})$, succinate $(0.01 \mathrm{mM})$, and hydrogen $(0.2$ $\mathrm{ml} \mathrm{ml}$ of culture $\left.{ }^{-1}\right)$. Esculin, gelatin, and casein were digested, and milk gave a curd reaction, while indole, catalase, ammonia, lipase, and nitrate reduction were not detected. Growth of strain $\mathrm{B} 316^{\mathrm{T}}$ on CC-glucose medium was slow but was stimulated by the addition of $20 \%$ rumen fluid; growth was not affected by Tween 80 and hemin and was inhibited by bile. When cells were grown in CC-glucose medium containing $20 \%$ rumen fluid, they reached a maximum optical density at 600 $\mathrm{nm}$ of approximately 0.75 after 5 to $6 \mathrm{~h}$ with a lag time of $1.11 \mathrm{~h}$ and a specific growth rate of $0.49 \mathrm{~h}^{-1}$ (equivalent to a generation time of $1.44 \mathrm{~h}$ ).

Proteinase activity and inhibition. The proteolytic activity of strain $\mathrm{B} 316^{\mathrm{T}}$ was investigated by using different substrates and proteinase inhibitors (Fig. 2). Strain B316 ${ }^{\mathrm{T}}$ hydrolyzed casein at approximately nine times the rate at which FILP was attacked (Fig. 2a). High rates of hydrolysis of casein compared with hydrolysis of FILP have also been reported for Prevotella ruminicola R8/4 (10) and for whole rumen contents (17) and have been attributed to differences in the solubilities of these substrates. Strain B316 ${ }^{\mathrm{T}}$ proteinase activity was inhibited to the greatest extent by phenylmethylsulfonyl fluoride and to lesser extents by merthiolate, $N$-tosyl-1-lysine chloromethyl ketone, $p$-chloromercuribenzote, EDTA, and $o$-phenanthroline, indicating that this organism contains mainly serine type proteinases, as well as some cysteine proteinase and metalloproteinase activities (Fig. 2b). N-Tosyl-1-phenylalanine chloromethyl ketone and pepstatin A both enhanced strain $\mathrm{B} 316^{\mathrm{T}}$ proteolytic activity slightly, indicating that chymotrypsin and aspartic acid proteinase activities, respectively, were absent.

Relatedness to other taxa. Strain $\mathrm{B} 316^{\mathrm{T}}$ can be clearly differentiated from the gram-positive, rod-shaped species belonging to the genera Eubacterium and Lachnospira on the basis of carbon source utilization, end product formation, and $\mathrm{G}+\mathrm{C}$ content data (Table 1). Strain B316 ${ }^{\mathrm{T}}$ was originally described as Butyrivibrio-like (1), and phenotypically it is similar to $\mathrm{Bu}$ tyrivibrio fibrisolvens; strain $\mathrm{B} 316^{\mathrm{T}}$ differs from this organism mainly in its lower $\mathrm{G}+\mathrm{C}$ content, its lack of dextrin utilization, and its lack of motility. Also, strain B316 ${ }^{\mathbf{T}}$ cells are only slightly 

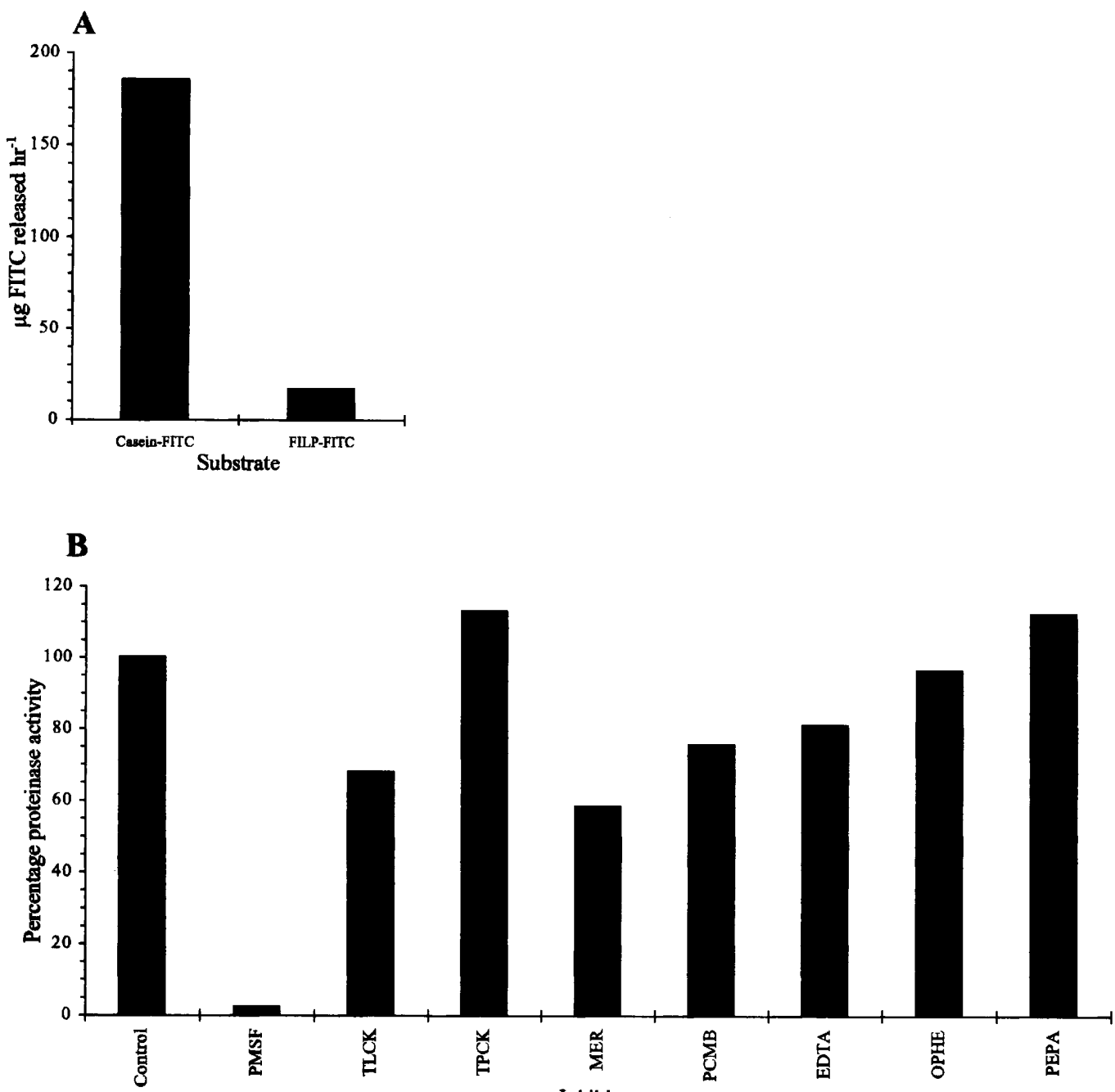

FIG. 2. Strain $B 316^{\mathrm{T}}$ proteinase activity and proteinase inhibition. Strain $\mathrm{B} 316^{\mathrm{T}}$ cells were assayed by using fluorescein isothiocyanate-labelled casein or FILP (A) and azocasein with or without proteinase inhibitors (B). Abbreviations: FITC, fluorescein isothiocyanate; PMSF, phenylmethylsulfonyl fluoride; TLCK, $N$-tosyl-1-lysine chloromethyl ketone; TPCK, $N$-tosyl-1-phenylalanine chloromethyl ketone; MER, merthiolate; PCMB, $p$-chloromercuribenzoate; OPHE, $o$-phenanthroline; PEPA, pepstatin A.

curved rods and do not form helical chains, whereas $B$. fibrisolvens is easily identified as it has a distinct vibrio morphology.

Phylogenetic analysis. The complete $16 \mathrm{~S}$ rRNA gene of strain $\mathrm{B} 316^{\mathrm{T}}$ was sequenced, and the resulting sequence was compared with representative bacterial sequences. The strain $\mathrm{B} 316^{\mathrm{T}}$ sequence was found to be most similar to sequences from members of the clostridial group of organisms. Additional sequences from this region were chosen and used to construct a similarity matrix (Table 2). Strain B316 ${ }^{\mathrm{T}}$ was most similar to the hyper-ammonia-producing rumen bacterium Clostridium aminophilum. Two other clostridial species, Clostridium oroticum and Clostridium aminovalericum, were also closely related. The similarity matrix was used to construct the dendrogram shown in Fig. 3. Strain B316 ${ }^{\mathrm{T}}$ was most similar to C. aminophilum and another rumen inhabitant, Acetitomaculum ruminis. This places strain $\mathrm{B} 316^{\mathbf{T}}$ in clostridial subcluster XIVa within the proposed family Ruminococcaceae (8). A similar comparison which included the unpublished 16S rRNA sequences of several $B$. fibrisolvens strains (9a) confirmed that strain $\mathrm{B} 316^{\mathrm{T}}$ was most closely related to $C$. aminophilum, although most of the Butyrivibrio sequences fell within the same clostridial subcluster, subcluster XIVa. This subcluster is both phenotypically and phylogenetically diverse, and many of its member species do not conform to the Clostridium genus description (gram-positive, obligately anaerobic, endosporeforming rods which are not able to carry out dissimilatory sulfate reduction). Strain B316 ${ }^{\mathrm{T}}$ clearly belongs in this cluster, but genus allocation is difficult because of the distance to its closest neighbor (level of similarity, 92.2\%) and its phenotypic similarities to $B$. fibrisolvens. However, because of the likely revision of the clostridia (8), we believe that it is best to describe strain B316 ${ }^{\mathrm{T}}$ as a new species of the genus Clostridium as an interim measure. A review of clostridial subcluster XIVa is likely to define a number of new genera, and it would be premature to assign strain $B 316^{\mathbf{T}}$ to a new taxon. Therefore, we propose that strain $\mathrm{B} 316^{\mathrm{T}}$ should be included in the genus Clostridium as a member of a new species, $C$. proteoclasticum.

Description of Clostridium proteoclasticum sp. nov. Clostridium proteoclasticum (pro.te.o.clas'ti.cum. M. L. neut. n. proteinum, protein, from G. v. proteuein, to be first; M. L. adj. clasticus, breaking, from G. part. perf. klastos, broken; proteoclasticum M. L. adj. protein breaking). Cells are gram-positive, straight 
TABLE 1. Differential characteristics for strain $B 316^{\mathrm{T}}$ and anaerobic, gram-positive, nonsporing, rod-shaped bacteria from the rumen ${ }^{a}$

\begin{tabular}{|c|c|c|c|c|c|c|c|c|c|}
\hline \multirow[b]{2}{*}{ Taxon } & \multicolumn{5}{|c|}{ Substrate utilization ${ }^{b}$} & \multirow{2}{*}{$\begin{array}{l}\text { Fermentation end } \\
\text { products }^{c}\end{array}$} & \multirow{2}{*}{$\begin{array}{c}\text { Flagellar } \\
\text { arrangement }^{d}\end{array}$} & \multirow[b]{2}{*}{ Motility } & \multirow{2}{*}{$\begin{array}{l}\mathrm{G}+\mathrm{C} \text { content } \\
\quad(\mathrm{mol} \%)\end{array}$} \\
\hline & Arabinose & Cellulose & Dextrin & $\begin{array}{l}\text { Inulin, melibiose, } \\
\text { mannose, rhamnose }\end{array}$ & Xylan & & & & \\
\hline $\mathrm{B} 316^{\mathrm{T}}$ & + & - & - & + & + & $\mathrm{F}, \mathrm{b}, \mathrm{a}, \mathrm{H}_{2}$ & $\mathrm{~m}$, st & - & 28 \\
\hline Butyrivibrio fibrisolvens & + & d & + & + & d & $\mathrm{F}, \mathrm{B}, \mathrm{A}, \mathrm{l}, \mathrm{s}, \mathrm{H}_{2}$ & $\mathrm{~m}, \mathrm{l}, \mathrm{t}, \mathrm{st}$ & + & $36-41$ \\
\hline Eubacterium cellulosolvens & - & + & - & - & $\mathrm{d}$ & $\mathbf{L}, \mathbf{f}, \mathbf{b}, \mathbf{a}, \mathbf{s}, \mathbf{H}_{2}$ & $\mathrm{p}$ & + & $\mathrm{NR}^{f}$ \\
\hline Eubacterium ruminantium & $\mathrm{d}$ & - & - & - & $\mathrm{d}$ & $\mathrm{L}, \mathrm{F}, \mathrm{B}, \mathrm{a}, \mathrm{p}$ & - & - & NR \\
\hline Eubacterium limosum & $\mathrm{d}$ & - & - & - & NR & $\mathrm{L}, \mathrm{A}, \mathrm{B}, \mathrm{H}_{2}$ & - & - & 47 \\
\hline Lachnospira multiparus & - & - & NR & d & - & $\mathrm{F}, \mathrm{A}, \mathrm{L}, \mathrm{s}, \mathrm{H}_{2}$ & $\mathrm{~m}, \mathrm{st}, \mathrm{la}$ & + & NR \\
\hline
\end{tabular}

${ }^{a}$ Data from references 3,4 , and 16 .

$b+$, substrate utilized; - , substrate not utilized; d, substrate utilization varies between strains.

${ }^{c} \mathrm{~A}$ and $\mathrm{a}$, acetate; $\mathrm{B}$ and $\mathrm{b}$, butyrate; $\mathrm{F}$ and $\mathrm{f}$, formate; $\mathrm{L}$ and $\mathrm{l}$, lactate; p, propionate; $\mathrm{s}$, succinate; $\mathrm{H}_{2}$, hydrogen. Uppercase letters indicate major products, and lowercase letters indicate minor products or occasional products of some strains.

${ }^{d} \mathrm{~m}$, monotrichous; 1 , lophotrichous; $\mathrm{p}$, peritrichous; $\mathrm{t}$, terminal, st, subterminal; la, lateral; - , no flagella present.

$e^{e}$, not motile; + , motile.

${ }^{\prime} \mathrm{NR}$, not reported.

to slightly curved rods that are 0.4 to $0.6 \mu \mathrm{m}$ wide and 1.3 to 3.0 $\mu \mathrm{m}$ long and do not form endospores. Cells occur in short chains and have tapered ends, and each cell possesses a single, subterminal flagellum, although cells are not motile in liquid culture. After overnight incubation, cells form a ropy sediment, which is easily dispersed with shaking. Colonies grown overnight on CC-glucose medium are $0.5 \mathrm{~mm}$ in diameter, tan, irregular, convex with undulate margins, and transparent with smooth surfaces and a viscous texture. Older colonies ( 2 to 3 days) are $1 \mathrm{~mm}$ in diameter and become granular.

Growth characteristics. Growth is supported by amygdalin, arabinose, cellobiose, fructose, galactose, glucose, inulin, lactose, maltose, melibiose, rhamnose, salicin, starch, sucrose, xylan, and xylose, while glycogen and mannose support weak growth. The substrates adonitol, cellulose, dextrin, dulcitol, erythritol, galacturonic acid, glycerol, inositol, lactate, mannitol, melizitose, sorbitol, sorbose, and trehalose do not support growth. The fermentation products from growth on $\mathrm{CC}$ medium include formate, butyrate, acetate, propionate, and a trace of succinate. Hydrogen is produced from growth on CCglucose medium. Growth is stimulated by the presence of $20 \%$ rumen fluid, is inhibited by bile, and is not affected by Tween 80 or hemin. There is no growth aerobically.

Characterization tests and $\mathbf{G}+\mathbf{C}$ content. $C$. proteoclasticum hydrolyzes gelatin and casein, and proteolytic activity against casein is almost totally inhibited by phenylmethylsulfonyl flu-

TABLE 2. Levels of $16 \mathrm{~S}$ rDNA similarity between strain $\mathrm{B} 316^{\mathrm{T}}$ and some related taxa

\begin{tabular}{|c|c|c|c|c|c|c|c|c|c|c|c|c|c|c|c|c|c|}
\hline \multirow[b]{2}{*}{ Species $^{a}$} & \multicolumn{17}{|c|}{$\%$ Similarity } \\
\hline & 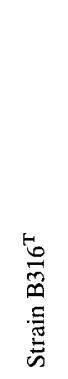 & 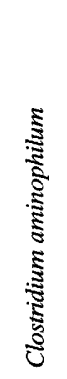 & 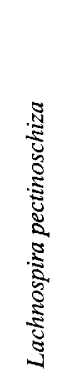 & 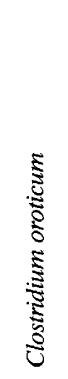 & 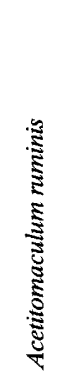 & 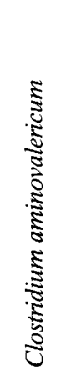 & 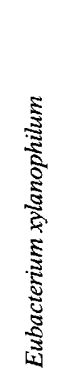 & 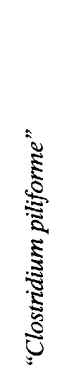 & 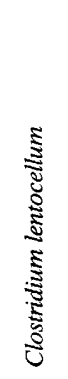 & 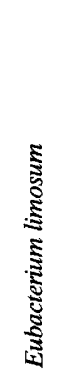 & 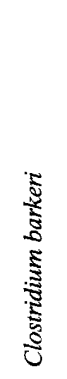 & 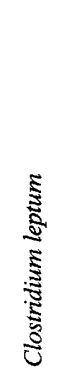 & 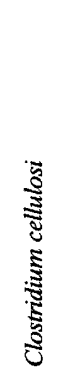 & 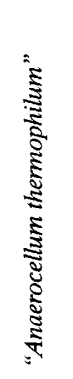 & 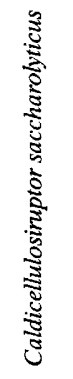 & 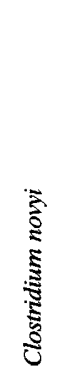 & 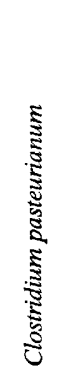 \\
\hline Clostridium aminophilum & 92.2 & & & & & & & & & & & & & & & & \\
\hline Lachnospira pectinoschiza & 88.2 & 89.1 & & & & & & & & & & & & & & & \\
\hline Clostridium oroticum & 88.5 & 90.2 & 91.0 & & & & & & & & & & & & & & \\
\hline Acetitomaculum ruminis & 87.8 & 89.5 & 88.2 & 89.3 & & & & & & & & & & & & & \\
\hline Clostridium aminovalericum & 88.5 & 89.6 & 90.1 & 92.2 & 90.1 & & & & & & & & & & & & \\
\hline Eubacterium xylanophilum & 87.4 & 88.4 & 91.1 & 90.9 & 89.6 & 92.7 & & & & & & & & & & & \\
\hline "Clostridium piliforme" & 84.3 & 85.4 & 87.1 & 88.6 & 86.5 & 87.7 & 86.9 & & & & & & & & & & \\
\hline Clostridium lentocellum & 84.2 & 85.1 & 86.4 & 87.8 & 86.1 & 87.1 & 88.0 & 87.0 & & & & & & & & & \\
\hline Eubacterium limosum & 82.1 & 82.8 & 82.1 & 83.3 & 83.4 & 83.3 & 82.5 & 82.8 & 82.7 & & & & & & & & \\
\hline Clostridium barkeri & 82.0 & 82.2 & 82.4 & 82.7 & 84.0 & 83.1 & 82.9 & 82.4 & 81.8 & 95.5 & & & & & & & \\
\hline Clostridium leptum & 83.3 & 84.7 & 83.1 & 83.9 & 85.9 & 84.4 & 84.7 & 82.2 & 84.1 & 83.0 & 83.0 & & & & & & \\
\hline Clostridium cellulosi & 81.9 & 82.9 & 81.4 & 82.1 & 84.0 & 82.1 & 81.9 & 81.3 & 82.2 & 83.1 & 81.4 & 88.1 & & & & & \\
\hline "Anaerocellum thermophilum" & 80.6 & 82.8 & 81.1 & 81.3 & 83.0 & 82.1 & 80.9 & 80.8 & 81.3 & 82.0 & 81.3 & 83.3 & 85.3 & & & & \\
\hline Caldicellulosiruptor saccharolyticus & 80.4 & 82.7 & 80.8 & 81.0 & 82.4 & 81.8 & 80.8 & 80.6 & 81.6 & 81.8 & 82.4 & 83.3 & 84.1 & 96.3 & & & \\
\hline Clostridium novyi & 81.3 & 83.0 & 84.0 & 85.3 & 83.2 & 84.4 & 84.7 & 82.6 & 84.0 & 84.4 & 84.1 & 84.5 & 84.1 & 82.0 & 82.0 & & \\
\hline Clostridium pasteurianum & 80.5 & 82.7 & 83.5 & 84.4 & 82.5 & 84.0 & 84.0 & 82.7 & 83.7 & 84.2 & 83.8 & 83.6 & 83.5 & 80.9 & 81.0 & 93.4 & \\
\hline Escherichia coli & 77.9 & 78.6 & 78.8 & 80.0 & 79.3 & 80.0 & 80.4 & 77.9 & 81.1 & 78.8 & 79.2 & 78.0 & 78.6 & 77.5 & 77.2 & 78.3 & 78.0 \\
\hline
\end{tabular}

${ }^{a}$ Quotation marks indicate that a name has not been validly published. 


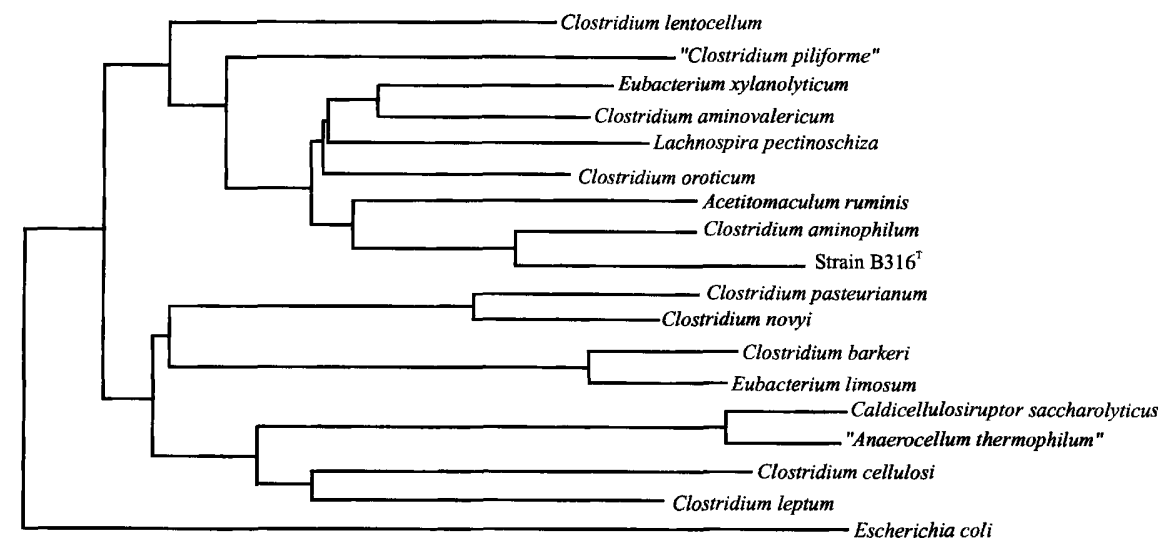

$\overbrace{0}^{0.01}$

FIG. 3. Phylogenetic tree showing the relationship of strain $\mathrm{B} 316^{\mathrm{T}}$ to other gram-positive anaerobic rods. The tree was derived from the similarity matrix shown in Table 2 . Scale bar $=1 \%$ difference in nucleotide sequences.

oride and is inhibited to lesser degrees by merthiolate, $N$-tosyl1-lysine chloromethyl ketone, $p$-chloromercuribenzote, EDTA, and $o$-phenanthroline. This organism also exhibits a curd reaction with milk and hydrolyzes esculin. $C$. proteoclasticum does not produce indole or ammonia, does not exhibit catalase, lipase, or lecithinase activity, and does not reduce nitrate. The heat test data, spore strain results, and growth on sporulation medium all indicate that no endospores are formed, while colonies on blood agar are nonhemolytic. The $\mathrm{G}+\mathrm{C}$ content of the DNA is 28 mol\% (as determined by the thermal denaturation method).

C. proteoclasticum strain B316 is the type strain and has been deposited in the American Type Culture Collection as strain ATCC 51982.

Occurrence and role of $C$. proteoclasticum in the rumen. Two strains with characteristics similar to those of $C$. proteoclasticum have been isolated from a different animal grazing in a pasture and were sufficiently similar in their phenotypic characteristics to fall in the same cluster as strain $\mathrm{B} 316^{\mathrm{T}}(1)$. These strains were also isolated from high dilutions $\left(10^{-8}\right)$ of rumen fluid, so $C$. proteoclasticum-like organisms appear to be common in New Zealand cattle in significant numbers. The ability of $C$. proteoclasticum to break down FILP and to utilize a range of carbohydrates places it among the proteolytic-saccharoclastic rumen bacteria which ferment the soluble carbohydrates released from the breakdown of plant fiber (cellulose and hemicellulose) and obtain their nitrogen by breaking down plant protein. C. proteoclasticum is not able to grow on peptone-yeast extract alone and does not produce ammonia as a result of fermentation, indicating that it is not involved in the fermentation of peptides, as is its closest relative, $C$. aminophilum. C. proteoclasticum is therefore likely to be involved in the primary hydrolysis of feed protein to peptides and possibly amino acids. Further studies on the 16S rDNA-based probes and the proteinases of $C$. proteoclasticum are currently under way to determine the contribution of $C$. proteoclasticum-like organisms to protein breakdown in New Zealand ruminants.

\section{ACKNOWLEDGMENTS}

The assistance of Graham Naylor with HPLC and gas chromatography analyses and the technical assistance of Doug Hopcroft and Raymond Bennett with electron microscopy of negatively stained and thin-sectioned cell preparations are gratefully acknowledged. We thank Gavin Rees and Alan Sheehy at the University of Canberra for the use of facilities for $\mathrm{G}+\mathrm{C}$ content determinations. Appreciation is also expressed to Andrew Hudson and Keith Joblin for constructive criticisms of the manuscript.

This work was funded by the Public Good Science Fund of the Foundation for Research in Science and Technology and by an equipment grant from the New Zealand Lotteries Foundation.

\section{REFERENCES}

1. Attwood, G. T., and K. Reilly. 1995. Identification of proteolytic rumen bacteria isolated from New Zealand cattle. J. Appl. Bacteriol. 79:22-29.

2. Brock, F. M., C. W. Forsberg, and J. G. Buchanan-Smith. 1982. Proteolytic activity of rumen microorganisms and effects of proteinase inhibitors. Appl. Environ. Microbiol. 44:561-569.

3. Bryant, M. P. 1984. Butyrivibrio, p. 641-643. In N. R. Krieg and J. G. Holt (ed.), Bergey's manual of systematic bacteriology, vol. 1. The Williams \& Wilkins Co., Baltimore.

4. Bryant, M. P. 1984. Lachnospira, p. 661-662. In N. R. Krieg and J. G. Holt (ed.), Bergey's manual of systematic bacteriology, vol. 1. The Williams \& Wilkins Co., Baltimore.

5. Charney, J., and R. M. Tomarelli. 1947. A colorimetric method for the determination of the proteolytic activity of duodenal juice. J. Biol. Chem. 171:501-505.

6. Chen, G., and J. B. Russell. 1988. Fermentation of peptides and amino acids by a monensin-sensitive ruminal Peptostreptococcus. Appl. Environ. Microbiol. 54:2742-2749.

7. Chen, G., and J. B. Russell. 1989. More monensin-sensitive, ammoniaproducing bacteria from the rumen. Appl. Environ. Microbiol. 55:10521057.

8. Collins, M. D., P. A. Lawson, A. Willems, J. J. Cordoba, J. FernandezGarayzabal, P. Garcia, J. Cai, H. Hippe, and J. A. E. Farrow. 1994. The phylogeny of the genus Clostridium: proposal of five new genera and eleven new species combinations. Int. J. Syst. Bacteriol. 44:812-826.

9. Doetsch, R. N. 1981. Determinative methods of light microscopy, p. 21-33. In P. Gerhardt, R. G. E. Murray, R. N. Costilow, E. W. Nester, W. A. Wood, N. R. Krieg, and G. B. Phillips (ed.), Manual of methods for general bacteriology. American Society for Microbiology, Washington, D.C.

9a.Forster, R. Personal communication.

10. Hazlewood, G. P., and R. Edwards. 1981. Proteolytic activities of a rumen bacterium, Bacteroides ruminicola R8/4. J. Gen. Microbiol. 125:11-15.

11. Holdeman, L. V., and W. E. C. Moore. 1972. Anaerobe laboratory manual. Virginia Polytechnic Institute and State University, Blacksburg.

12. Jukes, T. H., and C. R. Cantor. 1969. Evolution of protein molecules, p. 21-132. In H. N. Munro (ed.), Mammalian protein metabolism, vol. 3. Academic Press, Inc., New York.

13. Leedle, J. A. Z., and R. B. Hespell. 1980. Differential carbohydrate media and anaerobic replica plating technique in delineating carbohydrate utilizing subgroups in rumen bacterial populations. Appl. Environ. Microbiol. 39:709719.

14. MacRae, J. C., and M. J. Ulyatt. 1974. Quantitative digestion of fresh herbage by sheep. II. The sites of digestion of some nitrogenous constituents. J. Agric. Sci. 82:309-319.

15. Maniatis, T., E. F. Fritsch, and J. Sambrook. 1982. Molecular cloning: a laboratory manual. Cold Spring Harbor Press, Cold Spring Harbor, N.Y. 
16. Moore, W. E. C., and L. V. Holdeman-Moore. 1986. Eubacterium, p. $1353-$ 1373. In P. H. A. Sneath, N. S. Mair, M. E. Sharpe, and J. G. Holt (ed.) Bergey's manual of systematic bacteriology, vol. 2. The Williams \& Wilkins Co., Baltimore.

17. Nugent, J. H. A., and J. L. Mangan. 1978. Rumen proteolysis of fraction 1 leaf protein, casein and bovine serum albumin. Proc. Nutr. Soc. 37:48A.

18. Nugent, J. H. A., and J. L. Mangan. 1981. Characteristics of the rumen proteolysis of fraction I (18S) leaf protein from lucerne (Medicago sativa L.) Br. J. Nutr. 46:39-59.

19. Rees, G. N., G. S. Grassia, A. J. Sheehy, P. P. Dwivedi, and B. K. C. Patel. 1995. Desulfacinum infernum gen. nov., sp. nov., a thermophilic sulfatereducing bacterium from a petroleum reservoir. Int. J. Syst. Bacteriol. 45: $85-89$

20. Russell, J. B., H. J. Strobel, and G. Chen. 1988. The enrichment and isolation of a ruminal bacterium with a very high specific activity of ammonia production. Appl. Environ. Microbiol. 54:872-877.

21. Saito, H., and K.-I. Miura. 1963. Preparation of transforming deoxyribonucleic acid by phenol treatment. Biochim. Biophys. Acta 72:619-629.

22. Saitou, N., and M. Nei. 1987. The neighbor-joining method: a new method for reconstructing phylogenetic trees. Mol. Biol. Evol. 4:406-425.

23. Sanger, F., S. Nicklen, and A. R. Coulson. 1977. DNA sequencing with chain-terminating inhibitors. Proc. Natl. Acad. Sci. USA 74:5463-5467.

24. Spiers, A. G., and D. H. Hopcroft. 1992. Some electron microscope observations of conidium ontogeny of Sphaceloma murrayae on Salix. N. Z. J. Bot. 30:353-358.

25. Twining, S. S. 1984. Fluorescein isothiocyanate-labelled casein assay for proteolytic enzymes. Anal. Biochem. 143:30-34

26. Wallace, R. J., and K. N. Joblin. 1985. Proteolytic activity of a rumen anaerobic fungus. FEMS Microbiol. Lett. 29:19-25. 